\title{
Hesperidin Increases Cytotoxic Effect of 5-Fluorouracil on WiDr Cells
}

\author{
Yurista Gilang ${ }^{1}$, Adam Hermawan ${ }^{2}$, Aditya Fitriasari ${ }^{1}$, Riris Istighfari Jenie ${ }^{2 *}$ \\ ${ }^{1}$ Cancer Chemoprevention Research Center, Faculty of Pharmacy, Universitas Gadjah Mada, Yogyakarta \\ Jalan Sekip Utara 555281 (Phone. 02746492662 Fax. 543120) http://ccrc.farmasi.ugm.ac.id \\ ${ }^{2}$ Department of Pharmaceutical Chemistry, Faculty of Pharmacy, Universitas Gadjah Mada, Yogyakarta \\ Jalan Sekip Utara 555281
}

\begin{abstract}
Therapy of colon cancer by using 5-FU often causes problems of resistance. This encourages the development of co-chemotherapy agent. One of the compounds that could potentially be used as a co-chemotherapy agent is hesperidin. This study was conducted to determine the cytotoxic effects of hesperidin, 5-FU and the combination of them, as well as apoptosis induction in colon cancer cells WiDr. Cytotoxic effect of hesperidin, 5-FU, and its combination were observed using MTT assay. Observation of apoptosis was done by double staining method using ethidium bromide-acridin orange. Until 48 hours incubation, hesperidin showed no cytotoxic effects. Cytotoxic effects of 5-FU was observed after 48 hours with the $\mathrm{IC}_{50}$ value of $422 \mu \mathrm{M}$. However, hesperidin improved the cytotoxic effects of 5-FU at 48 hour incubation. Either single treatment of hesperidin $200 \mu \mathrm{M}$ or 5 -FU $1500 \mu \mathrm{M}$ did not trigger apoptosis, but combination of them led to the emergence of signs of apoptosis. Based on this study, it can be concluded thathesperidin is potential to be developed as a co-chemotherapy agent of 5-FU on colon cancer but still need further study on its molecular mechanisms.
\end{abstract}

Keywords: hesperidin, 5-fluorouracil, WiDr cells, cytotoxic, apoptosis

\section{INTRODUCTION}

The alteration of life style, dietary, change and lower physical activity increase the incidence of colon cancer (Center et al., 2009). Dharmais Hospital reported that colon cancer was included in big ten of cancer in Indonesia (Medical Record of Dharmais Hospital, 2009). Thus, the best therapy was needed to improve the quality of life and prevent mortality of colon cancer patient. Chemotherapeutic agent 5-fluorouracil (5-FU) isthe first choice for the treatment of colon cancer (Priestman, 2008). This chemotherapeutic agent acts as competitive substrate for the enzyme thymidylate synthetase (TS). Thymidylate synthetase is an enzyme which synthesizedeoxythymidine-5'-monophosphate (dTMP) as anecessary precursor in the synthesisof DNA (Matuo et al., 2008). Resistanceof cancer cells to5-FU caused treatment using 5-FU remains ineffective (Meyerhardt and Mayer, 2005; Giovannetti et al., 2007). Therefore, one of the strategies to improve the effectiveness of chemotherapy agent is by using the chemopreventive agent (Priestman, 2008).

Hesperidin is one of flavonoid contained in citrus peel and potential to be used as a chemopreventive agent in vitro and in vivo. Hesperidin showed cytotoxic effects on Caco 2 cells, CEM/ADR5000, and CCRF-CEM with $\mathrm{IC}_{50} 195,230$, and $95 \mu \mathrm{M}$ respectively (ElReadiet al., 2009). Melanogenesis in mouse melanoma cells could be inhibited by hesperidin through tyrosinasediphenolase with $\mathrm{IC}_{50} 16.08 \mu \mathrm{M}$ (Zhang et al., 2007). Hesperidin also inhibits the proliferation of MCF-7 cells which were transfected with green fluorescent protein (GFP)/alpha-tubulin (Lee et al., 2009). Hesperidin inhibits the proliferation of lung cancer cells in mice induced benzo[a]pyrene (Kamaraj et al., 2008). Hesperidin induces apoptosis on colon cancer cells through decrease in protein expression of $\mathrm{Bcl}-2$ and procaspase-3, increased expression of $\mathrm{Bax}$ protein, and activation of caspase-3 (Park et al., 2008). Therefore, hesperidin could be used as a co-chemoterapeutic agent on colon cancer.

\footnotetext{
*Corresponding author e-mail: ririsjenie@gmail.com
} 
This study was conducted to develop agents which could enhance the effectiveness of 5 -FU in the treatment of colon cancer. This study was performed in vitro using WiDr cells. WiDrcells showed low sensitivity to 5-FU (Liu et al., 2006). Therefore, it is interesting to examine whether the sensitivity of WiDr cancer cells to 5-FU could be enhanced by hesperidin as co-chemotherapeutic agent.

\section{MATERIALS AND METHODS}

\section{Cells Culture}

WiDr cells were obtained from Cancer Chemoprevention Research Center, Faculty of Pharmacy, Universitas Gadjah Mada. Cells were grown in Roswell Park Memorial Institute (RPMI) 1640 (Gibco) with 10\% Fetal Bovine Serum (Gibco) and $1 \%$ PenicillinStreptomycin (Gibco) at $37^{\circ} \mathrm{C}$ in a humidified atmosphere of $5 \% \mathrm{CO}_{2} / 95 \%$ air.

\section{Cell Viability Assay}

Cell viability assays were performed using MTT assay. WiDr cells were seeded at a density of $5 \times 10^{3}$ cells/well and allowed to attach for $24 \mathrm{~h}$. One day after initial seeding, cells were treated with either various concentrations of hesperidin (Sigma) alone, 5FU alone and their combination. After $48 \mathrm{~h}$ of incubation, culture medium was removed and cells were washed with PBS (Sigma). Then, cells were added with $100 \mu \mathrm{L}$ MTT (Sigma) 5 $\mathrm{mg} / \mathrm{mL}$ diluted with culture medium in each well for 4-6h. Stopper reagent was added after formazan formation prior to MTT reduction and incubated for one night in dark room. The absorbance of each well was measured using ELISA reader at $595 \mathrm{~nm}$ (Bio-Rad). The $\mathrm{IC}_{50}$ was determined using Excell MS Office 2007 and probit analysis (SPSS 11.5).

\section{Apoptosis Detection}

Apoptosis was detected using acrydine orange-ethidium bromide staining (AO/EB double staining). WiDr cells $\left(5 \times 10^{4}\right.$ cells/well $)$ were seeded on coverslips in 24-well plates until 50-60\% confluent. Cells were then incubated with hesperidin alone, 5-FU alone and their combination for $24 \mathrm{~h}$. Culture medium was removed and cells were washed with PBS. Coverslips were placed into object-glass and added with $10 \mu \mathrm{L} \quad 1 \mathrm{X}$ working solution acrydine orange (Sigma)-ethidium bromide (Sigma), then were observed under fluoroscence microscopy (Zeiss MC 80). Apoptotic cells which had lost their membrane integrity was appeared as orange cells and showed morphological features of apoptosis. Cells were identified as apoptotic cells based on specific morphological criteria, including condensation and fragmentation of chromatin, also formation of apoptotic bodies.

\section{RESULTS AND DISCUSSION}

\section{Effect of Hesperidin and 5-Fu on WiDr Cell Viability}

Cell viability assay was done to determine the inhibitory concentration $\left(\mathrm{IC}_{50}\right)$ of hesperidin alone, 5-FU alone and their combination on WiDr cells. Hesperidin did not show cytotoxic effect even after 48 hour incubation (Fig.1), while 5-FU had the $\mathrm{IC}_{50}$ values of $422 \mu \mathrm{M}$ after 48 hour of treatment (Fig.2). However, hesperidin increased cytotoxic effect of 5-FU. Cell viability caused by combination of 5-FU $500 \mu$ Mand hesperidin $200 \mu \mathrm{M}$ was lower than cell viability even caused by even with highest concentration of 5FU solely (1500 $\mu \mathrm{M})$ (Fig.3). Combination of hesperidin and 5-FU also altered morphology of WiDr cells. 


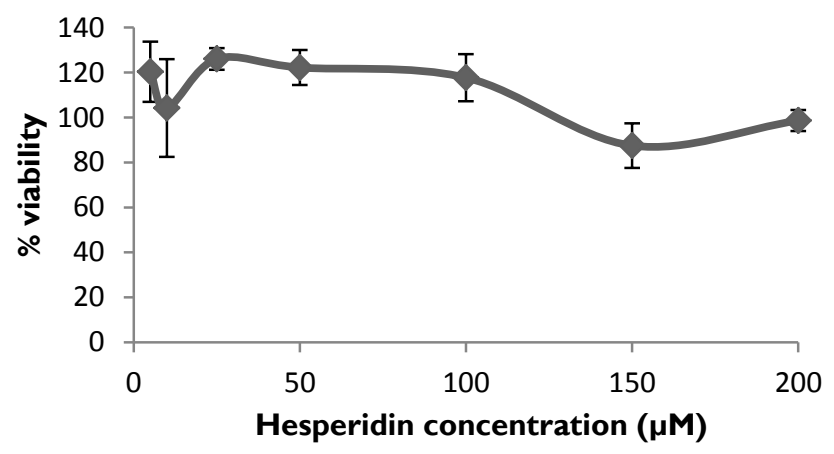

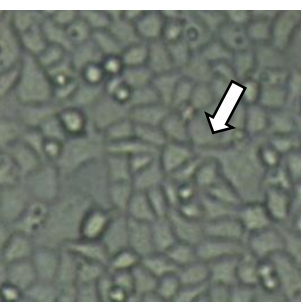

(B)

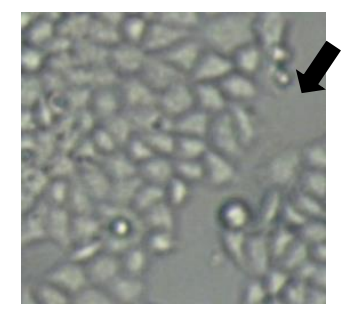

(C)

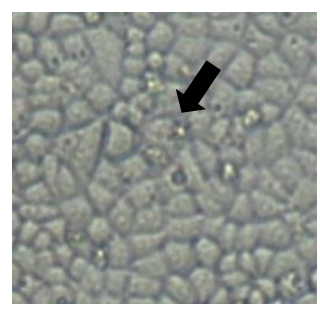

(D)

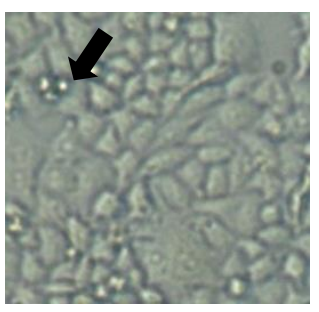

(E)

Figure I. Effect of hesperidin on WiDr Cell'sViability.WiDr cells with density $\left(5 \times 10^{3}\right)$ were treated by hesperidin $(5-200 \mu \mathrm{M})$ and incubated for 48 hours. Cells viability were obtained from the conversion of absorbance values of formazan that formed by MTT treatment as described in the materials and method. Incubation of hesperidin for 48 hour did not show cytotoxic effect at WiDr cell (A), compared to cell control (B) alteration of morphology was shown at concentration of hesperidin of $50 \mu M$ (C) and $100 \mu M$ (D), 200 $\mu M$ (E). Description: $\Rightarrow$ normal WiDr cells, $\Rightarrow$ cells undergoing morphological changes.

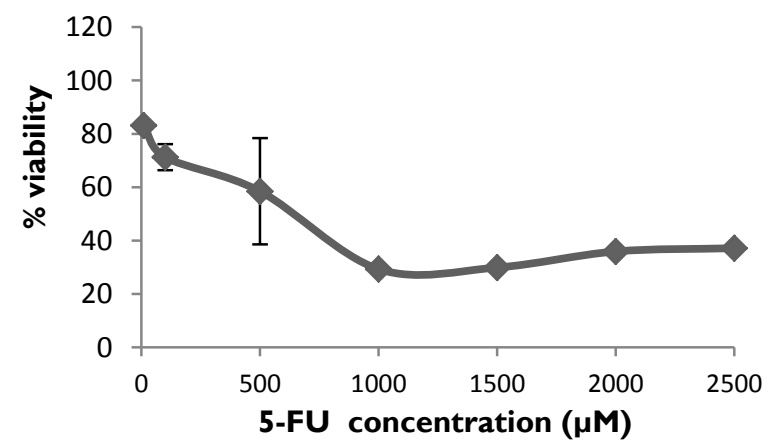

(A)

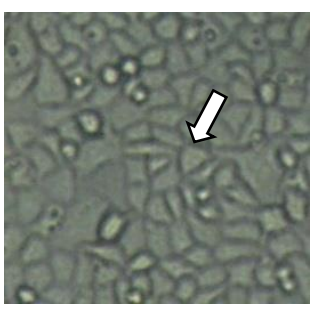

(B)

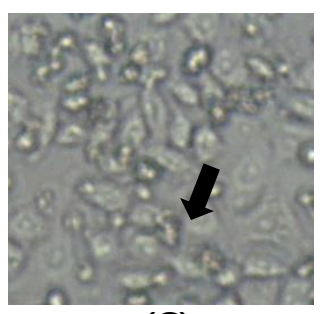

(C)

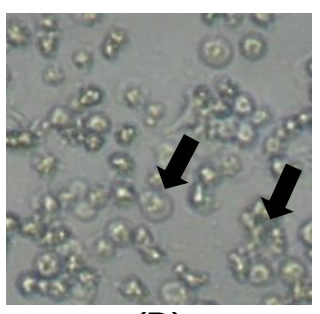

(D)

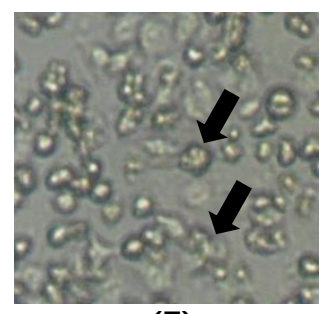

(E)

Figure 2. Effect of 5-FU on WiDr cell Viability. WiDr cells with density $\left(5 \times 10^{3}\right)$ were treated by 5FU $(10-2500 \mu \mathrm{M})$ and incubated for 48 hours. Cells viability were obtained from the conversion of absorbance values of formazan that formed by MTT treatment as described in the research procedure. Incubation of 5-FU for $\mathbf{4 8}$ hour lower the cell viability of WiDr cell (A), if we compared to cell control (B) alteration of morphology was shown at concentration of hesperidin of $500 \mu M$ (C) and $1000 \mu M$ (D), $2500 \mu M$ (E). Description: $\Rightarrow$ normal WiDr cells, $\rightarrow$ cells undergoing morphological changes. 


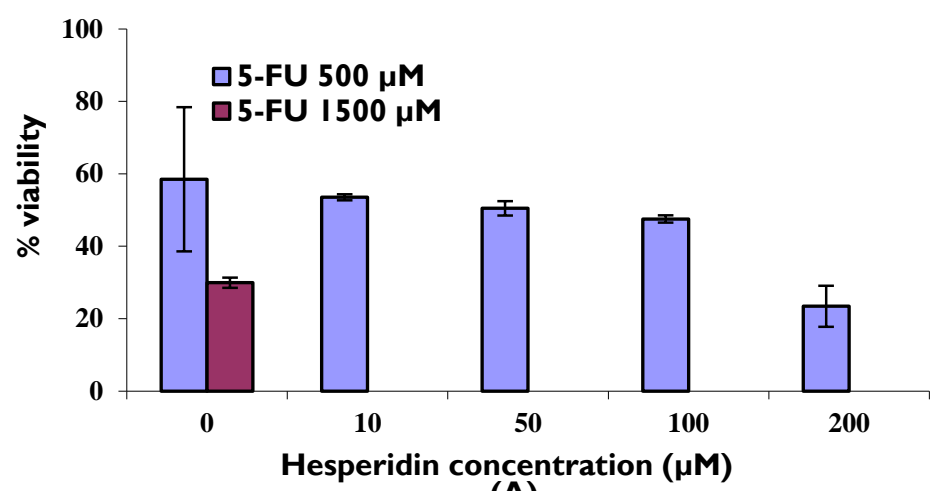

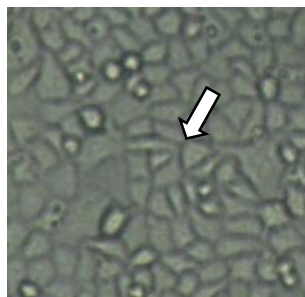

(B)

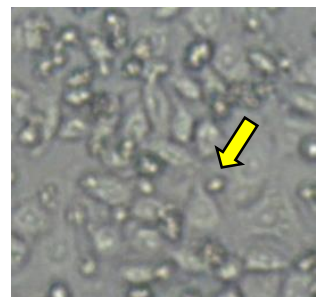

(C)

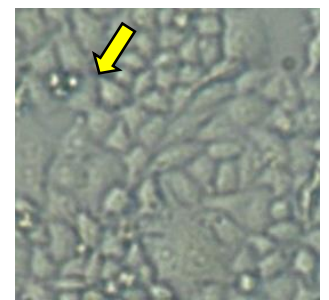

(D)

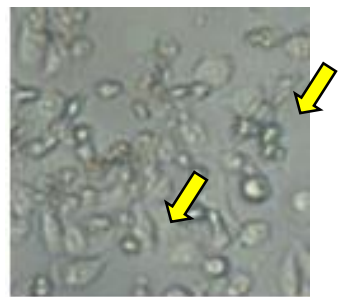

(E)

Figure 3. Effects of combination of hesperidin and 5-FU on WiDr cell viability. WiDr cells with density $\left(5 \times 10^{3}\right)$ were treated by 5-FU $(500 \mu \mathrm{M})$, hesperidin $(10,50,100,200 \mu \mathrm{M})$ and combination of both incubated for 48 hours. Cells viability were obtained from the conversion of absorbance values of formazan that formed by MTT treatment as described in the research procedure. Hesperidin was increase the cytotoxic effect of 5-FU (A). The morphology observation was using inverted microscope at magnification 400x. Hesperidin $200 \mu M$ (D), 5-FU $500 \mu M$ (C) or combination of both agent (E) produce the alteration of

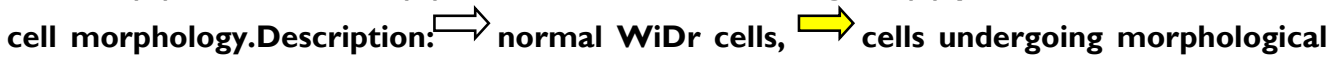
changes.

\section{Effects of Hesperidin and 5-FU on Apoptosis.}

Both of hesperidin and 5-FU were not able to induce apoptosis at single treatment of 5-FU $1500 \mu \mathrm{M}$ or hesperidin $200 \mu \mathrm{M}$. Interestingly, combination of hesperidin and 5-

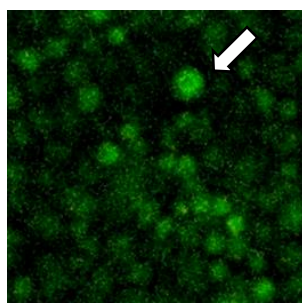

(A)

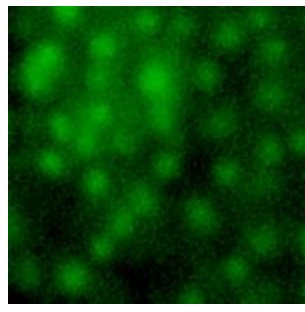

(B)

FU was able to induce apoptosis. The green fluorescence indicates the viable cells while the orange-red fluorescence indicates the death cells. Apoptotic cells were indicated by occurrence of chromatin condensation and the orange-red apoptotic bodies.

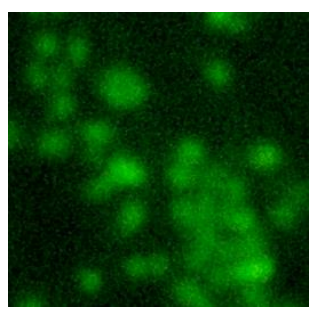

(C)

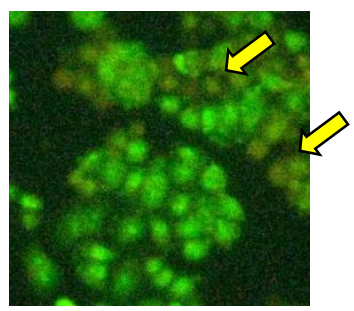

(D)

Figure 4. Effect of Hesperidin and 5-FU on apoptosis. Cells were treated with (A) control cells (untreated), (B) 5-FU $1500 \mu \mathrm{M},(C)$ hesperidin $200 \mu \mathrm{M}$, and (D) combination of 5-FU I500 $\mu \mathrm{M}$ and hesperidin $200 \mu \mathrm{M}$ at incubation time $24 \mathrm{~h}$. Cells was stained with acrydine orangeethidium bromide and observed under fluorosence microscope with 100x magnification. Yellow arrow $(\vec{b})$ indicating apoptotic cells, while white arrow $(\vec{\square})$ indicating viable cells. 
The results showed that hesperidin treatment up to 48 hours incubation showed no cytotoxic activity and apoptosis induction against WiDr cells. This result is similar with study conducted by Lee et al. (2009) which reported that treatment of hesperidin $100 \mu \mathrm{M}$ for 72 hours on MC-7-GF-Tubulin showed no cytotoxic effects but only antiproliferative effect. WiDr cells undergo morphological changes due to treatment hesperidin. Cells became larger after treated with hesperidin. This may be due to cell cycle arrest caused by hesperidin. Therefore, further research needs to be conducted to observe the effects of hesperidin on cell cycle arrest.

Chemotherapeutic agent is expected to induce apoptosis of cancer cells. Single treatment of 5-FU for 48 hours were able to demonstrate cytotoxic effect. Long term use of 5-FU caused cancer cells resistance to apoptosis induction (Violette et al., 2002). Chemotherapeutic agent 5-FU induces IкB $\alpha$ degradation thus increasing the activation of $\mathrm{NF}-\kappa \mathrm{B}$ and increases the translocation and binding of NF-kB to DNA (Wang et al., 2003; Voboril et al., 2004). NF- $\mathrm{KB}$ activation will further increase the expression of $\mathrm{Bcl}-2$ and $\mathrm{Bcl}-\mathrm{XL}$ which are antiapoptosis protein (Ruddon, 2007). Cytotoxic activity of hesperidin combination with 5-FU after 48 hours showed a stronger cytotoxic effect as well as induce apoptosis than single treatment of 5FU. This results demonstrated the ability of hesperidin in increasing the sensitivity of cancer cells to 5-FU.

One possibility according to hesperidin activity is hesperidin increases 5-FU transport into the cells. Hesperidin treatment caused changes in cell morphology, including changes in the cell membrane that may occur due to membrane fluidity alteration. Membrane fluidity influence passive transport of a compound and affects the number of molecules compound that enter the cells (Hendrich and Michalak, 2003). Change in membrane fluidity is likely to cause 5 - FU is not only transported by specific carrier by active transport but also through passive transport. This phenomenon increase the 5-FU influx, thereby increasing the effectiveness of 5-FU against WiDr cells. Research done by Callaghan et al. (1993) stated that interference with membrane fluidity may increase the amount of drug entry into the cell, thereby increasing the cell's sensitivity. Nevertheless, further research on hesperidin effect against changes in membrane fluidity and increase transport of 5-FU into the cells still needs to be done.

Based on these results, the cytotoxic effect of 5-FU could be enhanced with the use of hesperidin as co-chemotherapeutic agent. Hesperidin also increased the apoptosis induction together with the use of 5-FU. The use of hesperidin as combination agents may also reduce the dose of 5-FU and expected to reduce the risk of side effects of 5-FU in colon cancer chemotherapy.

\section{ACKNOWLEDGEMENT}

We would like to thank Cancer Chemoprevention Research Center (CCRC) Faculty of Pharmacy Universitas Gadjah Mada for the research support.

\section{REFERENCES}

Callaghan, R., Stafford, A. and Epand, R.M., 1993, Increased Accumulation of Drugs in A Multidrug Resistant Cell Line by Alteration of Membrane Biophysical Properties, Biochim. Biophys. Acta, I I 75(3), 277-282.

Center, M.M., Ahmedin J., Robert A.S. and Elizabeth W., 2009, Worldwide Variations in Colorectal Cancer, CA Cancer J. Clin., 59, 366-378.

El-Readi, M.Z., Hamdan, D., Farrag, N., ElShazly, A. and Wink, M., 2009, Inhibition of P-glycoprotein Activity by Limonin and Other Secondary Metabolites from Citrus Species in Human Colon and Leukaemia Cell Lines, Eur. J. Pharmacol., 626, I39-I 45.

Lee, C.J., Wilson, L., Jordan, M.A., Nguyen, V., Tang, J. and Smiyun, G., 2009, Hesperidin Suppressed Proliferations of Both Human Breast Cancer and Androgen-dependent Prostate Cancer Cells, Phytother. Res., 24, I5-19.

Liu, H.C., Chen, G.G., Vlantis, A.C., Leung, B.C.S., Tong, M.C.E. and van Hasselt, C.A., 2006, 5-Fluorouracil Mediates Apoptosis and GI/S Arrest in Laryngeal Squamous Cell Carcinoma via a $\mathrm{p} 53$-Independent Pathway, The Cancer J., I 2(6), 482-493.

Matuo, R., Sousa, F.G., Escargueil, A.E., Grivicich, I., Garcia-Santos, D., Chies, J.A.B., Saffi, J., Larsen, A.K. and 
Henriques. J.A.P., 2008, 5-Fluorouracil and Its Active Metabolite FdUMP Cause DNA Damage in Human SW620 Colon Adenocarcinoma Cell Line, J. Appl. Tox., 29, 308-316.

Meyerhardt, J.A. and Mayer, R.J., 2005, Systemic Therapy for Colorectal Cancer, N. Engl. J. Med., 352(5), 476487.

Park, H.J., Kim, M.J., Ha, E., and Chung, J.H., 2008, Apoptotic Effect of Hesperidin Through Caspase3 Activation in Human Colon Cancer Cells, SNU-C4, Phytomedecine, I5(I-2), I47-I5I.

Priestman, T., 2008, Cancer Chemotherapy In Clinical Practice, Springer, London, 9698.

Rekam Medis RSKD, 2009, StatistikKanker: 10

Besar Kanker Tersering RSKD Rawatjalan (KasusBaru) tahun 2007, diambildarihttp://www.dharmais.co.id/i ndex.php/cance-statistic.html, accessed on March 2010.

Ruddon, R.W., 2007, Cancer Biology 4th ed., Oxford University Press, New York, I5I-I58.

Violette, S., Poulain, L., Dussaulx, E., Pepin, D., Faussat, A.M., Chambaz, J., Lacorte, J.M., Staedel, C., and Lesuffleur, T., 2002, Int. J. Cancer, 98(4), 498-504.

Voboril., R., Hochwald, S.N., Li, J., Brank. A., Wessels, F., Moldawer, L.L., Camp, E.R. and Mackay, S.L., 2004, Inhibition of NF-kappa B Augments Sensitivity to 5-fluorouracil/Folinic Acid in Colon Cancer, J. Surg. Res., I 20(2), I78-188.

Wang, W., McLeod, H., and Cassidy, J., 2003, Disulfiram-mediated Inhibition of NFkappaB Activity Enhances Cytotoxicity of 5-Fluorouracil in Human Colorectal Cancer Cell Lines, Intl. J. Canc., I 04(4), 504-5II. 